\title{
The Use of Seagrass Ecology Context on Student Worksheets to Improve Student Scientific Literacy
}

\author{
Abdul Syukur ${ }^{1,2, *}$, Lalu Zulkifli ${ }^{1,2}$, Mahrus ${ }^{1,2}$, Kumala Ratna Dewi $^{1}$ \\ ${ }^{1}$ Department of Sciences Education Postgraduate, ${ }^{2}$ Department of Biological Sciences Education \\ ${ }^{1,2}$ Mataram University \\ Mataram, Indonesia \\ *syukurbiologi@unram.ac.id
}

\begin{abstract}
Environmental characteristics in coastal areas are receiving less attention, especially for science education development. However, it provides relevant learning objectives, such as the presence of seagrass and marine aquaculture. This study aims to develop environmental-based student worksheet using seagrass context to improve students' scientific literacy. The method employed in this research is a quasi-experimental. Data was collected using instrument test and observation sheet. Data was analysed using descriptive statistical analysis technique. The results showed that the worksheet contained seagrass ecology approach were theoretically valid according to the judgement expert with the average value $A$ (very good). The synthesis of student worksheets contained seagrass and marine aquaculture's ecological value also found can significantly increase students' scientific literacy. This results suggest that integrating local natural resources into teaching and learning process in the form of student worksheet strengthens students' literacy and sensitivity to the coastal areas of East Lombok and global environmental issues.
\end{abstract}

Keywords-ecological value, seagrass ecology, student worksheets, science literacy

\section{INTRODUCTION}

Seagrass areas in East Lombok's coastal waters are scattered along the mainland coastal waters of Lombok Island and small islands. The total area of seagrass in the southern part of East Lombok, which is around the waters of Tanjung Luar, is 264.60 ha and found 118 fish species associated with seagrass [1]. Also, in waters with seagrass areas, such as in Lombok's southern coastal waters, there is a diversity of marine biota species such as bivalves and echinoderms [2]. Another potential of East Lombok's coastal waters is the marine environment, the bay's waters, and has been used by the community to develop aquatic cultivation. In this regard, seagrass's ecological services are a location for taking seeds for cultivation, such as economically important fish and cuttlefish $[3,4]$. The strategic values of marine cultivation practices by the community are: (1) protection from exploitation of resources such as seagrass ecosystems, (2) small-scale fishers have alternative livelihoods, (3) increase the participation of fishers and local communities in protecting local scale seagrass and (4) ) Raise awareness of the importance of togetherness's value to create a sense of security and comfort in people's social lives [4].

Local natural resources such as seagrass beds and marine culture are relevant learning resources to be developed, especially for contextual learning development. The two are learning objects (marine cultivation and seagrass ecosystem services) above can be extracted into relevant teaching materials at each level of education. Furthermore, the extract of results has been using for the development of teaching materials [5]. It is necessary because the extraction of teaching materials from the local environment has benefits including (1) local materials can be a cognitive bridge between abstraction and the realities of daily life of students (2) sources of teaching materials from the local environment enable teachers and students thinking has the initial cognitive similarity to be developed at a higher cognitive level, (3) local materials are present as a substitute for rare and expensive teaching materials (4) local materials can save costs, (5) local materials contribute to the achievement of educational goals because provide opportunities to develop scientific skills, attitudes, and practical skills and (6) local materials to some extent fill the gaps or absence of learning resources [6,7]. The concept of learning base on the local environment can be synthesis in student worksheets. In addition, local potential-based learning is quite effective in improving students' generic skills [8]. In this regard, environmental innovation-based science student worksheets significantly increase students' critical thinking power and scientific attitude in junior high schools [9]. However, students' obstacles are discovering new scientific explanations for findings that are classifying into several components, including a lack of initial knowledge, barriers to complex material structures, and failure of creative cognitive processes [10].

The 2013 curriculum has the same challenges expected in scientific literacy, namely facing the rapid advancement of the times and various problems related to environmental issues, advances in technology and information, the rise of creative and cultural industries, and education development. A guided inquiry learning model can have applied to learn to improve students' scientific literacy skills. It is based on previous research results to enhance students' scientific literacy skills and enhance the learning process. Guided inquiry-based 
teaching materials so that students are expecting to achieve optimal competence [11]. The presence of student worksheets is quite relevant to the scientific learning model because it can facilitate student creativity to find a concept and develop various scientific skills to overcome student learning barriers [12]. The preliminary observations results that the integration of local environmental issue in to student worksheets is still rare to be done. This research aims to develop the student worksheets that integrating the seagrass ecosystem services and marine cultivation and evaluation its impact on students' scientific literacy performance.

\section{MATERIAL AND METHODS}

This research has been conducting in the odd semester of the 2020/2021 school year, at the Pantai Desa Junior High School in East Lombok Regency. The method used in this research is a quasi-experimental with nonequivalent pre-testpost-test control group design. The guided inquiry with marine cultivation-based student worksheets was implemented in the experimental class, while the conventional student worksheets applied in the control class. The population of this study was all schools in the research location. The data of scientific literacy skills was collected using an instrument test and analyzed using descriptive statistics.

\section{RESULTS AND DISCUSSION}

\section{A. Environmental-Based Student Worksheet}

The development of student worksheet was carrid out by integrating local wisdom in the context of seagrass ecology. Prior to use in the teaching and learning process, the Seagrass ecology-based students worksheet was evaluated for its content validity to get judgement expert and also users. The results for the worksheet assessment is shown in Table 1-3.

TABLE I. EXPERT JUDGEMENT ON THE STUDENT WORKSHEET FORMAT

\begin{tabular}{|l|l|l|l|l|}
\hline No & \multicolumn{1}{|c|}{ Aspect Score } & \multicolumn{1}{|c|}{ Score } & Value & Category \\
\hline 1 & Language & 3.5 & A & Very good \\
\hline 2 & Characteristics & 4 & A & Very good \\
\hline 3 & $\begin{array}{l}\text { Complete student } \\
\text { worksheets Format }\end{array}$ & 4 & A & Very good \\
\hline 4 & Presentation & 3.5 & A & Very good \\
\hline 5 & Technical Usage & 3 & B & good \\
\hline & Average & & A & Very good \\
\hline
\end{tabular}

TABLE II. MATERIAL EXPERT VALIDATION ASSESSMENT

\begin{tabular}{|l|l|l|l|l|}
\hline No & \multicolumn{1}{|c|}{ Aspect Score } & \multicolumn{1}{|c|}{ Score } & Value & Category \\
\hline 1 & Content eligibility & 3.7 & A & Very good \\
\hline 2 & Language & 4 & A & Very good \\
\hline 3 & Characteristics & 4 & A & Very good \\
\hline & Average & & & Very good \\
\hline
\end{tabular}

TABLE III. ASSESSMENT OF PRACTICALITY BY THE TEACHER

\begin{tabular}{|l|l|l|l|l|}
\hline No & \multicolumn{1}{|c|}{ Aspect Score } & \multicolumn{1}{|c|}{ Score } & \multicolumn{1}{c|}{ Value } & Category \\
\hline 1 & Language & 4 & A & Very good \\
\hline 2 & Characteristics & 3.5 & A & Very good \\
\hline 3 & $\begin{array}{l}\text { Complete student } \\
\text { worksheets Format }\end{array}$ & 3.8 & A & Very good \\
\hline 4 & Presentation & 3.5 & A & Very good \\
\hline 5 & Technical Usage & 3.6 & A & Very good \\
\hline & Average & & A & Very good \\
\hline
\end{tabular}

As can be seen in Table 1-3, the results for student worksheet assessment showed that the developed product is judged to be valid and valued to be implemented in the teaching and learning process. The seagrass ecology is integrated into the worksheet and applied to the experimental class to measure whether or not the local wisdom integration may boost students' scientific literacy. The teaching and learning was initiated with a pre-test then the effect of the treatment was evaluated through post-test. Scientific literacy can be interpreted as the ability to understand the scientific process and engage with scientific information in everyday life [13]. The main component of scientific literacy is understanding science content, namely the basic science concepts. The second group of "scientific literacy" views scientific literacy as a requirement to adapt to the challenges of a rapidly changing world [14]. The effectiveness local environmental-based worksheet on students' literacy in the coastal area of East Lombok is shown in Figure 1.

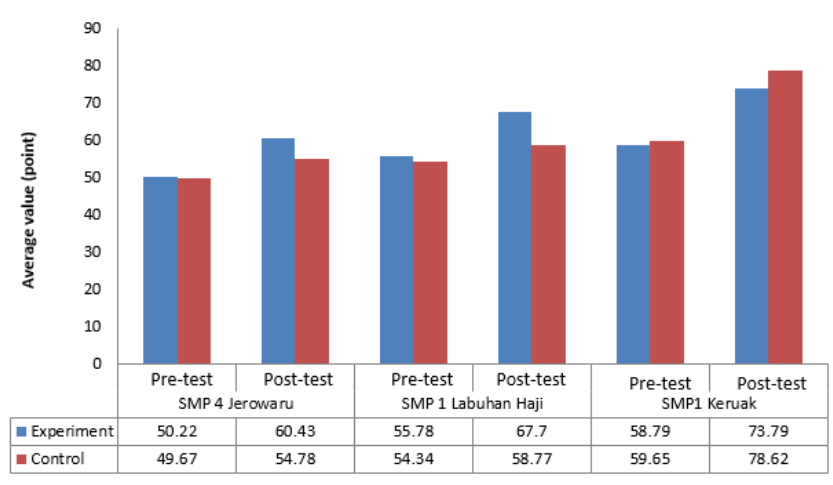

Fig. 1. The effect of seagrass ecology-based worksheet on students'science literacy ability.

The assessment of students' scientific literacy abilities showed (Figure 1) that the initial average pre-test results showed almost identical average value between the two classes used for this current research, indicating ability in both research classes are homogenous. The effect of Seagrass ecology-based worksheet were generally observed on students' literacy ability in experimental in three school, except students in SMP 1 Keruak. These results imply that the use of student worksheets IPA as a learning supplement that uses the ecology of seagrass can improve students' scientific literacy skills. The higher achievement of students' ability in SMP 1 Keruak might be caused by the higher ability of students in control class of SMP 
1 Keruak. The independent sample t-test analysis also showed that differences of students'scientific literacy significantly increased in the experimental class than those of the control class (Table 4).

TABLE IV. RESUlTS OF THE INDEPENDENT SAMPLE T-TEST ANALYSIS

\begin{tabular}{|c|c|c|c|c|c|c|c|}
\hline Name of School & \multicolumn{2}{|c|}{ Class } & $\mathbf{t}$ & df & $\begin{array}{l}\text { Sig. (2- } \\
\text { tailed) }\end{array}$ & $\begin{array}{c}\text { Mean } \\
\text { Difference }\end{array}$ & $\begin{array}{l}\text { Std. Error } \\
\text { Difference }\end{array}$ \\
\hline \multirow[t]{4}{*}{ SMP 4 Jerowaru } & \multirow[t]{2}{*}{ Experiment } & Pre-Test & -4.733 & 61 & 0.000 & -10.938 & 2.263 \\
\hline & & Pos Tes & -4.733 & 52.314 & 0.000 & -10.938 & 2.263 \\
\hline & \multirow[t]{2}{*}{ Control } & Pre-Test & -9.164 & 56 & 0.000 & -25.517 & 2.815 \\
\hline & & Pos Tes & -9.164 & 54.684 & 0.000 & -25.517 & 2.815 \\
\hline \multirow{4}{*}{$\begin{array}{lll}\text { SMP } & 1 \text { Labuhan } \\
\text { Haji } & & \end{array}$} & \multirow[t]{2}{*}{ Experiment } & Pre-Test & -4.633 & 62 & 0.000 & -10.938 & 2.263 \\
\hline & & Pos Tes & -4.633 & 53.314 & 0.000 & -10.938 & 2.263 \\
\hline & \multirow[t]{2}{*}{ Control } & Pre-Test & -5.347 & 56 & 0.000 & -11.207 & 1.985 \\
\hline & & Pos Tes & -5.347 & 55.991 & 0.000 & -11.207 & 1.985 \\
\hline \multirow[t]{4}{*}{ SMP 1 Keruak } & \multirow[t]{2}{*}{ Experiment } & Pre-Test & -8.856 & 56 & 0.000 & -18.966 & 2.118 \\
\hline & & Pos Tes & -8.856 & 53.095 & 0.000 & -18.966 & 2.118 \\
\hline & \multirow[t]{2}{*}{ Control } & Pre-Test & -6.732 & 56 & 0.000 & -15.000 & 2.224 \\
\hline & & Pos Tes & -6.732 & 55.9784 & 0.000 & -15.000 & 2.224 \\
\hline
\end{tabular}

Science Literacy is one of the areas of PISA (Program for International Student Assessment), which focuses on a person's ability to use scientific knowledge and skills in making decisions and solving problems. Scientific literacy is an individual's scientific knowledge and the capacity to use that knowledge to identify questions, acquire new knowledge, explain scientific phenomena, and draw evidence-based conclusions about issues related to science [15]. A study on the level of scientific literacy of secondary students conducted by the OECD in 2015 shows that Indonesia's student literacy group is still low. However, the point has increased from a study conducted in 2012 [16].

\section{CONCLUSION}

Student worksheets are vital to assist the learning process of students. The material sourced from seagrass ecology material can supplement students' scientific literacy skills in schools. Therefore, a more comprehensive teacher's cognitive abilities are needed to take advantage of the environment's potential in helping students' learning process. Also, the utilization of the surrounding environment's potential can increase awareness of preserving the environment through formal education.

\section{ACKNOWLEDGMENTS}

The author thanks the Rektor Mataram for providing funds to carry out this research.

\section{REFERENCES}

[1] Syukur, A., Wardiatno, Y., Muchsin, I., \& Kamal, M. M. (2017). Threats to seagrass ecology and indicators of the importance of seagrass ecological services in the coastal waters of East Lombok, Indonesia. American Journal of Environmental Sciences, 13(3), 251-265.

[2] Syukur, A., Al-Idrus, A., \& Zulkifli, L. (2020). Ecotourism development based on the diversity of echinoderms species in seagrass beds on the south coastal of Lombok island, Indonesia. Journal of Environmental Science and Technology, 13(2), 57-68.
[3] Syukur, A., \& Mahrus, S. A. (2016). The potential assessment environment friendly aquaculture of small-scale fishermen as a conservation strategy seagrass beds in coastal areas of Tanjung Luar East Lombok, Indonesia. management, 19(20), 21.

[4] Syukur, A., \& Mahrus, S. A. (2018). The Perspective of Small Fisherman toward the Seagrass Conservation Values for the Sustainability of Friendly Environmental Fish Farming: a Case Study in Coastal Waters of East Lombok

[5] Güçlüer, E., \& Kesercioğlu, T. (2012). The Effect of Using Activities Improving Scientific Literacy on Students' achievement In Science and Technology Lesson. International Online Journal of Primary Education (IOJPE) 1(1-12).

[6] Keselman, A. (2003). Supporting inquiry learning by promoting normative understanding of multivariable causality. Journal of Research in Science Teaching, 40(9), 898-921.

[7] Lin, H. S., Hong, Z. R., \& Huang, T. C. (2012). The role of emotional factors in building public scientific literacy and engagement with science. International Journal of Science Education, 34(1), 25-42.

[8] Pedaste, M., Mäeots, M., Siiman, L. A., De Jong, T., Van Riesen, S. A., Kamp, E. T., ... \& Tsourlidaki, E. (2015). Phases of inquiry-based learning: Definitions and the inquiry cycle. Educational research review, 14, 47-61.

[9] Utami, W. S. (2016). The Effectiveness of Geography Student Worksheet to Develop Learning Experiences for High School Students. Journal of Education and Learning, 5(3), 315-321.

[10] Misbah, M., Dewantara, D., Hasan, S. M., \& Annur, S. (2018). The development of student worksheet by using Guided Inquiry Learning Model to train student's scientific attitude. Unnes Science Education Journal, 7(1).

[11] Sari, R. R., \& Abdurrahman, K. (2020). Development and Validation of students' Worksheet Based on Guided-Inquiry to Improve Students' Scientific Literacy Skills of Junior High School on Straight Motion Concept. JPhCS, 1467(1), 012073.

[12] Fives, H., Huebner, W., Birnbaum, A. S., \& Nicolich, M. (2014) Developing a measure of scientific literacy for middle school students. Science Education, 98(4), 549-580.

[13] Utami, B., Saputro, S., Ashadi, A., \& Masykuri, M. (2016). Scientific literacy in science lesson. In International Conference on Teacher Training and Education. Sebelas Maret University.

[14] OECD. 2014. PISA 2012 Results in Focus What 15-Year-Olds Know and What They Can Do with What They Know. Paris:PISA OECD Publishing.

[15] OECD. 2016. PISA 2015 result in focus. Paris: PISA OECD Publishing 